\title{
NANOFIBRE ENCAPSULATION OF LIMONENE AND MODELLING ITS RELEASE MECHANISMS
}

\author{
S. Dede ${ }^{a}$, and F. Lokumcu Altay ${ }^{\text {** }}$

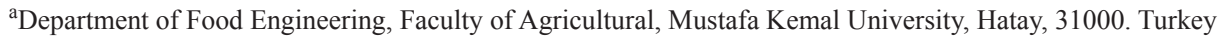 \\ ${ }^{\mathrm{b}}$ Department of Food Engineering, Faculty of Chemical and Metallurgical, Istanbul Technical University, Istanbul, \\ 34469. Turkey
}

(Received: 16 January 2018; accepted: 25 June 2018)

\begin{abstract}
In this study, limonene was encapsulated by using gelatine, Na-alginate, polyvinyl alcohol, lactalbumin or xanthan gum with the uniaxial electrospinning process. The highest encapsulation efficiency was obtained for the sample containing polyvinyl alcohol. The release kinetic studies of nanofibre encapsulated limonene were carried out at 5.5, 20 , and $38.5^{\circ} \mathrm{C}$. The Peppas equation expressed the release behavior of limonene for all systems very well, indicating quasi-Fickian diffusion. The modelling data suggested that maybe more than one mechanism was involved for the release at $20{ }^{\circ} \mathrm{C}$. The activation energy for releasing limonene from the electrospun polyvinyl alcohol-alginate encapsulation system was found to be $6.2 \mathrm{~kJ} \mathrm{~mol}^{-1}$ from the Arrhenius equation.

Keywords: nanoencapsulation, volatile components, nanofibres, release kinetics, food process modelling, biopolymers
\end{abstract}

Limonene (LM) is a non-polar flavouring compound of citrus fruit. Volatile materials with antimicrobial properties, such as LM, are of great interest for the active packaging industry, and their effective encapsulation and release kinetics have a great importance due to their high sensitivity to ambient conditions. It has bactericidal, antioxidant, and therapeutic properties, thus it is used in cosmetics, foods, and other consumer products (Li \& CHIANG, 2012).

Electrospinning is a simple, versatile, top-down process and an encapsulation method to produce nanofibres easily and cost effectively (ANU BHUSHANI \& ANANDHARAMAKRISHNAN, 2014; ОкитAN et al., 2014). When core and wall materials are mixed and pumped through the same tip to the electrical field, electrospun nanofibre is in the uniaxial form (Altay \& Okutan, 2015). High encapsulation efficiency (EE), sustained release of encapsulated material, suitable encapsulation method for heat-labile compounds, improved protection from detrimental conditions, enhanced stability and functionality of encapsulated material are the main advantages of the electrospinning procedure (ANU BHUSHANI \& ANANDHARAMAKRISHNAN, 2014).

Gelatine (GL) is a widely used polymer and is approved as wall material in encapsulation (GouRdel \& TRonel, 2001). Alginate (ALG) is a linear polysaccharide used as wall material due to its mechanical stability (BhatTarai et al., 2006). Polyvinyl alcohol (PVA) is cheap, biocompatible, and used as wall material due to its stability under most physiological conditions (Levi et al., 2011). Lactalbumin (LA) is a good stabilizer due to its good emulsifying property and high biocompatibility (VIJAYARAGAVAN et al., 2014). Xanthan gum (XG) is a

\footnotetext{
* To whom correspondence should be addressed.

Phone: +902122856948; e-mail: lokumcu@itu.edu.tr
} 
polysaccharide used as a wall material for encapsulation (RuTz et al., 2013). There are five different release mechanisms of the encapsulated material: 1) fracturation; 2) diffusion; 3) swelling and dissolution; 4) eroding and biodegradation; and 5) osmosis (Ko \& GunASEKARAN, 2014).

The objectives of this study were to nanoencapsulate LM by uniaxial electrospinning using PVA, GL, ALG, LA, or XG; to characterize electrospun fibres and to modell the release kinetics of the GL nanofibre encapsulated LM at different temperatures by various mathematical equations.

\section{Materials and methods}

\subsection{Materials}

LM (Alfa Aesar Co., Germany), ethanol (Sigma-Aldrich Co., Germany), type B gelatine powder from bovine skin (Sigma, Germany), PVA (ZAG, Turkey), XG (Sigma, Germany), Na-alginate E-401 (FMC-Biopolymer, US), LA (Sigma, Germany), and acetic acid (Merck, US) were purchased. The feed solutions, their composition and preparation are given in Table 1. All samples were mixed at 300 r.p.m.

Table1. Preparation and compositions of feed solutions

\begin{tabular}{llccccc}
\hline $\begin{array}{l}\text { Sample } \\
\text { no }\end{array}$ & $\begin{array}{c}\text { Wall } \\
\text { polymer(s) }\end{array}$ & $\begin{array}{c}\text { Polymer ratio } \\
(\mathrm{w} / \mathrm{w})\end{array}$ & $\begin{array}{c}\text { Total polymer } \\
\text { concentration in } \\
\text { the feed }(\mathrm{wt} \%)\end{array}$ & $\begin{array}{c}\text { Solvent } \\
(\mathrm{h})\end{array}$ & $\begin{array}{c}\text { Temperature } \\
\left({ }^{\circ} \mathrm{C}\right)\end{array}$ \\
\hline 1 & PVA & 8 & 8 & Distilled water & 1 & 80 \\
2 & PVA+ALG & $32: 0.15$ & 11 & Distilled water & 1 & 80 \\
3 & GL & 20 & 20 & $50 \%$ acetic acid & 2 & 60 \\
4 & GL+ALG & $19: 1$ & 20 & $50 \%$ acetic acid & 2 & 60 \\
5 & GL+LA & $19: 1$ & 20 & $50 \%$ acetic acid & 2 & 60 \\
6 & GL+XG & $8: 0.05$ & 11 & $50 \%$ acetic acid & 2 & 60 \\
\hline
\end{tabular}

Limonene to polymer solution ratio $(\mathrm{v} / \mathrm{v})$ was 1:9 for all samples; PVA: polyvinyl alcohol; LM: limonene; ALG: alginate; XG: xanthan gum; LA: lactalbumin

\subsection{Methods}

1.2.1. Electrospinning and characterization. The uniaxial electrospun encapsulation was performed by using electrospinning equipment (Inovenso NE100, Turkey) at $25{ }^{\circ} \mathrm{C}$. The applied voltage, the feed rate, and the distance to the collector plate were $25 \mathrm{kV}, 0.5 \mathrm{ml} \mathrm{h}^{-1}$, and $10 \mathrm{~cm}$, respectively.

The scanning electron microscope (SEM) (JEOL JSM-5500LV, Japan) was operated at an acceleration voltage of $10 \mathrm{kV}$ for morphological imaging of samples.

The translational diffusion coefficient measurement of dispersions containing electrospun nanofibre samples was carried out using a dynamic light scattering instrument (Malvern Zetasizer Nano ZS, Worcestershire, UK) at $25^{\circ} \mathrm{C}$ in triplicate. Ethanol or distilled water were used as dispersants and nanofibres were dispersed at $0.1 \%$ (w/v) (OKUTAN et al., 2014). The dynamic contact angles of samples were measured using a tensiometer 
(Dataphysics DCAT 11EC, Germany) by the Wilhelmy plate method at $25^{\circ} \mathrm{C}$. A sample with an area of $1 \mathrm{~cm} \times 1 \mathrm{~cm}$ and $1 \mathrm{~mm}$ height was placed onto a special holder of the tensiometer. The sample was brougth in contact with water and the contact angle value was read from the software (SCAT 11EC, Germany).

1.2.2. Encapsulation efficiency. After preparing a calibration curve of $\mathrm{LM}\left(\mathrm{R}^{2}=0.9995\right)$, all encapsulated samples were weighed out between $5.1 \mathrm{mg}$ and $14 \mathrm{mg}$ and dissolved in $5 \mathrm{ml}$ ethanol. Then, $1 \mu \mathrm{l}$ of each solution was injected in duplication into a gas chromatograph (GC) (Shimadzu GC 2010, Kyoto, Japan) to be captured in flame ionization detector (FID) compared to standard LM reference injected previously. Calculations were carried out by using external standard method. A polar capillary column (HP-Innowax $30 \mathrm{~m} \times 0.25 \mathrm{~mm}$ i.d $\times 0.25 \mu \mathrm{m}$ film thickness J\&W Scientific) was used for analyses (For working conditions: Supplementary data available at authors). The EE was calculated according to Eq. 1:

$$
E E=\frac{L M \text { amount captured by FID in GC }}{\text { LM amount in the feed solution }}
$$

This calculation is based on the ratio of the actual LM content in the fibre to theoretical LM content (WANG et al., 2017). The theoretical LM content in the electrospun fibres was the amount of LM added to the feed solution prior to the electrospinning.

1.2.3. Modelling of release mechanisms of LM. All electrospun samples (twice for each) were weighed and put into $5 \mathrm{ml}$ ethanol filled air tight tubes separately and stored at different temperatures $\left(5.5 \pm 1.5,20 \pm 1.0,38.5 \pm 1.5^{\circ} \mathrm{C}\right)$. One microlitre of the sample from each tube was taken and injected to GC at $0^{\text {th }}, 2^{\text {nd }}, 4^{\text {th }}$, and $6^{\text {th }}$ days to be captured in FID according to standard LM reference. Ethanol is a good simulant for fatty foods, easy to work with analytically (BANER et al., 1992), and can be used as release medium.

The release kinetics were modelled with various equations, such as the Peppas equation (Ritger \& Peppas, 1987), zero-order, first-order, Higuchi and Hixson-Crowell models (Supplementary data available from authors) (NEO et al., 2013; WANG et al., 2017). In this study, the Hixson-Crowell model was modified as follows according to Eq. 2:

$$
\left(1-\frac{M_{t}}{M_{\infty}}\right)^{1 / 3}=k t^{-n}
$$

The temperature dependency of the model parameter $(\mathrm{k})$ from the Peppas equation was expressed by the Arrhenius equation (Supplementary data from authors).

Excel 2016 (Microsoft, WA, USA) was employed for statistical analysis. The results of sample mean diameter were evaluated by the one-way analysis of variance (ANOVA) $(\alpha=0.05)$. The results of diffusion coefficients and contact angle were evaluated by the twoway ANOVA $(\alpha=0.05)$. Significant differences among samples were determined by the least significant difference comparison by the Student's paired $t$-test, and $t$-test probability limits of $\mathrm{P}<0.05$ were used for two-sided testing in evaluation. 


\section{Results and discussions}

\subsection{Electrospinnability and characterization of electrospun samples}

The SEM images of electrospun samples are given in Figure 1. All samples appear to be fibre except for sample 6 containing GL and XG. It is probably the complex and brunched structure of XG that inhibits electrospinnability.

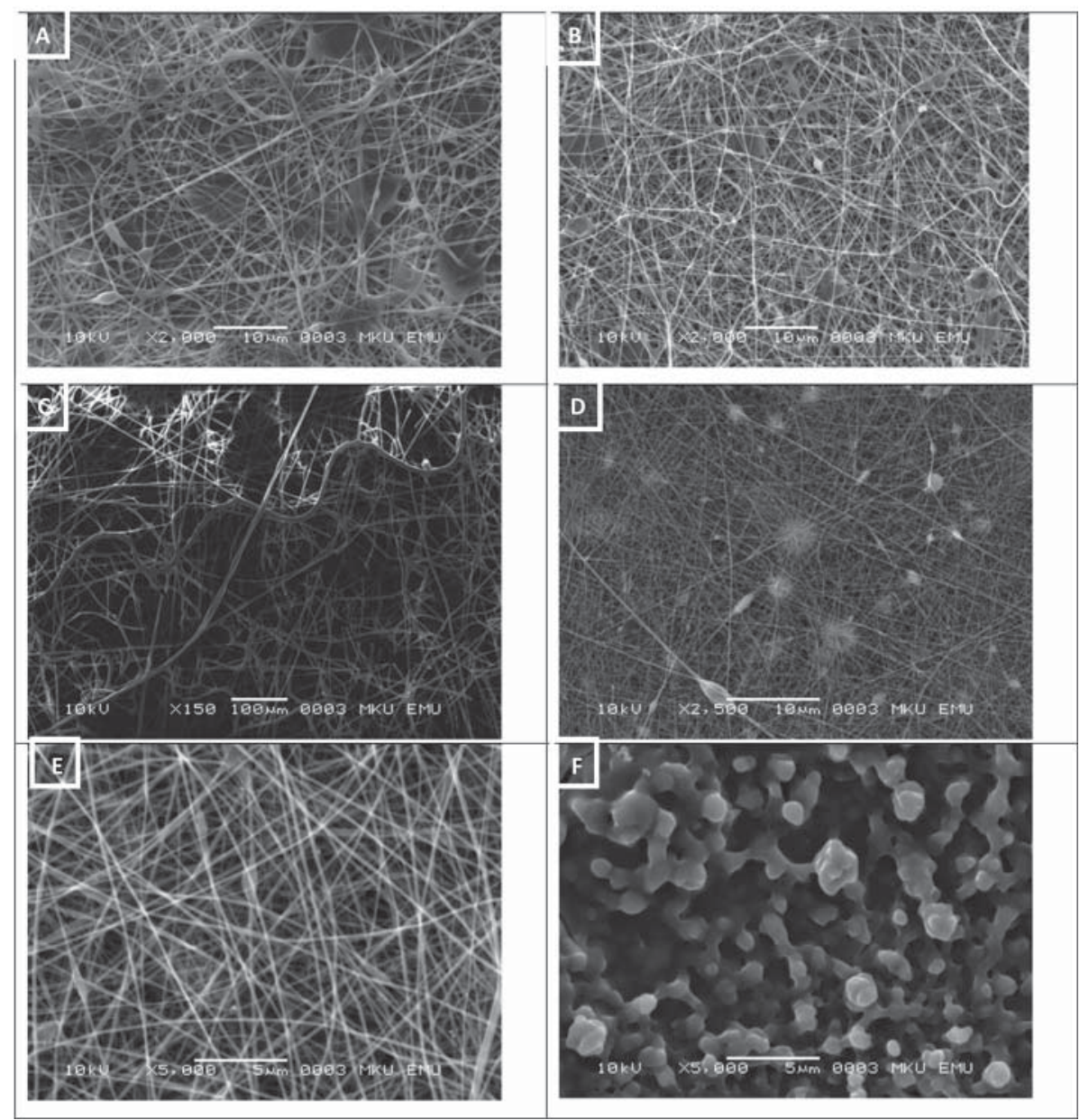

Fig. 1. SEM images of electrospun samples

A: Sample 1 (PVA+LM); B: Sample 2 (PVA+ALG+LM); C: Sample 3 (GL+LM);

D: Sample $4(\mathrm{GL}+\mathrm{ALG}+\mathrm{LM})$; E: Sample $5(\mathrm{GL}+\mathrm{LA}+\mathrm{LM}) ; \mathrm{F}$ : Sample $6(\mathrm{GL}+\mathrm{XG}+\mathrm{LM})$

PVA: polyvinyl alcohol; LM: limonene; ALG: alginate; XG: xanthan gum; LA: lactalbumin

The mean diameters of electrospun samples are listed in Table 2. Only sample 4 had the diameter lower than $100 \mathrm{~nm}$, which can be considered as nanofibre-encapsulated. The addition of ALG to the solutions of PVA or GL decreased the mean diameters of electrospun samples. It was also observed that the mean diameter of the sample containing GL (sample 3), having the highest diameter, decreased with the additions of LA or XG as well. CAMERLO and 
co-workers (2014) reported that diameters of electrospun nanofibres containing 9\% PVA and LM were in the range of 100-300 nm depending on the environmental conditions of electrospinning process. In our study we have found that the diameter of electrospun nanofibres with PVA-LM was $435.86 \pm 171.86 \mathrm{~nm}$.

Table 2. Mean diameters, encapsulation efficiencies (EE), diffusion coefficients, and contact angles of electrospun

\begin{tabular}{|c|c|c|c|c|c|c|}
\hline $\begin{array}{l}\text { Sample } \\
\text { no }\end{array}$ & $\begin{array}{l}\text { Electrospun } \\
\text { sample }\end{array}$ & $\begin{array}{c}\text { Sample mean } \\
\text { diameter }(\mathrm{nm})^{*}\end{array}$ & $\mathrm{EE}(\%)$ & $\begin{array}{l}\text { Samples in } \\
\text { ethanol (E) or } \\
\text { in water (W) }\end{array}$ & $\begin{array}{l}\text { Diffusion } \\
\text { coefficient } \\
\left(\mu \mathrm{m}^{2} \mathrm{~s}^{-1}\right)^{* *}\end{array}$ & $\begin{array}{c}\text { Contact angle } \\
\left({ }^{\circ}\right)^{* *}\end{array}$ \\
\hline \multirow[t]{2}{*}{1} & PVA+LM & $435.9 \pm 112.9 \mathrm{~b}$ & $117.0 \pm 0.33$ & $\mathrm{E}$ & $0.15 \pm 0.01 \mathrm{bcd}$ & $87.66 \pm 0.16 \mathrm{a}$ \\
\hline & & & & W & $1.37 \pm 0.03 \mathrm{a}$ & $81.48 \pm 4.28 \mathrm{a}$ \\
\hline \multirow[t]{2}{*}{2} & $\mathrm{PVA}+\mathrm{ALG}+\mathrm{LM}$ & $273.0 \pm 28.6 \mathrm{~b}$ & $50.5 \pm 4.02$ & $\mathrm{E}$ & $0.49 \pm 0.01 \mathrm{bc}$ & $93.09 \pm 4.26 \mathrm{a}$ \\
\hline & & & & W & $1.91 \pm 0.04 \mathrm{a}$ & $57.55 \pm 3.61 \mathrm{~b}$ \\
\hline \multirow[t]{2}{*}{3} & $\mathrm{GL}+\mathrm{LM}$ & $1830.0 \pm 291.2 \mathrm{a}$ & $100.0 \pm 0.53$ & $\mathrm{E}$ & $0.69 \pm 0.01 \mathrm{~b}$ & $78.86 \pm 3.41 \mathrm{a}$ \\
\hline & & & & W & $1.12 \pm 0.10 \mathrm{ab}$ & $60.85 \pm 5.30 \mathrm{~b}$ \\
\hline \multirow[t]{2}{*}{4} & $\mathrm{GL}+\mathrm{ALG}+\mathrm{LM}$ & $95.6 \pm 21.0 \mathrm{bcd}$ & $69.9 \pm 0.18$ & $\mathrm{E}$ & $0.25 \pm 0.00 \mathrm{bcd}$ & $79.09 \pm 10.51 \mathrm{a}$ \\
\hline & & & & W & $1.02 \pm 0.07 \mathrm{ab}$ & $52.34 \pm 2.59 \mathrm{~b}$ \\
\hline \multirow[t]{2}{*}{5} & $\mathrm{GL}+\mathrm{LA}+\mathrm{LM}$ & $225.8 \pm 29.7 \mathrm{bc}$ & $44.1 \pm 2.23$ & E & $0.28 \pm 0.07 \mathrm{bcd}$ & $92.83 \pm 0.04 \mathrm{a}$ \\
\hline & & & & W & $0.77 \pm 0.21 \mathrm{~b}$ & $89.82 \pm 0.23 \mathrm{a}$ \\
\hline 6 & $\mathrm{GL}+\mathrm{XG}+\mathrm{LM}$ & $1743.3 \pm 310.3 \mathrm{a}$ & - & - & - & - \\
\hline
\end{tabular}

* Means $\pm \mathrm{SD}(\mathrm{n}=3)$; values within each group followed by the same letter (in column, sample number) are not significantly different $(\mathrm{P} \leq 0.05)$

**Means $\pm \mathrm{SD}(\mathrm{n}=3)$; values within each group followed by the same letter (in column, sample number, and samples in ethanol or water) are not significantly different $(\mathrm{P} \geq 0.05)$

PVA: polyvinyl alcohol; LM: limonene; ALG: alginate; XG: xanthan gum

Diffusion coefficients (OKUTAN et al., 2014) and contact angle values (Dong et al., 2018) of electrospun nanofibres have been used for characterization (Table 2). Diffusion coefficient values of samples in water were higher than that of samples in ethanol for the samples containing PVA. It is probably due to the hydrophilic character of PVA, leading easy diffusion of samples to aquatic system.

All contact angle values showed that samples in water had relatively hydrophilic character compared to samples in ethanol. The contact angle values of sample 2, 3, and 4 decreased in water compared to the values in ethanol, meaning these samples showed more hydrophobic character (i.e. decreased wetting properties) in ethanol. The addition of LA increased the hydrophobicity of sample 5 in water compared to sample 3 and 4.

\subsection{Encapsulation efficiency}

The EE of LM was determined as between $44.12 \%$ and $117 \%$, which confirms that the electrospinning encapsulation was successful (Table 2). While the addition of LA to GL resulted in the lowest efficiency, the EE values of LM were obtained as $117 \pm 0.33 \%$, $50.5 \pm 4.02 \%, 100 \pm 0.53 \%$, and $69.91 \pm 0.18 \%$ for PVA, PVA+ALG, GL, and GL+ALG, respectively. It appears that addition of ALG to PVA or GL decreased the EE. 
Retention and release values of encapsulated anthocyanins exceeding $100 \%$ were explained as interference with the analysis due to the alcoholic extraction methods that do not include a chloroform extraction step to remove nonpolar compounds (FLORES et al., 2014). Venturini and co-workers (2011) calculated the EE as varying from $97.8 \pm 2.8 \%$ to $101.6 . \pm 0.5 \%(\mathrm{w} / \mathrm{w})$, although the concentration of the drug loading was constant, and explained it was due to drugs' lipophilicity, leading to high EE. Similarly, ethanol extraction of the samples may lead to interference in our analyses.

\subsection{Modelling of release mechanism}

The cumulative release profiles of LM versus time are given in Supplementary data, available at authors. Generally, a gradually increased release was observed for all samples if the timeline is considered, especially at $5.5^{\circ} \mathrm{C}$ (Supplementary data). This was probably because longer time was needed for the encapsulated LM in the electrospun sample to be released through a longer pathway (WANG et al., 2017).

The release kinetics of LM in ethanol were modelled and their model parameters are presented in Table 3. It appears that the Peppas equation expressed the release of LM from each polymer at all temperatures very well. The values of $\mathrm{n}$ were lower than 0.5 , indicating quasi-Fickian diffusion (El-Leithy et al., 2010), where LM was supposed to find its way out through interconnected small pores, spontaneously (BuENo et al., 2012). It means that the release mechanism was diffusion controlled (i.e. the release was caused by the concentration gradient between fibres and releasing medium) (BASAK et al., 2008) and stereoselective (because of $\mathrm{n}<0.5$ ) (BUENo et al., 2012).

Table 3. The kinetic models for release of LM

\begin{tabular}{|c|c|c|c|c|c|c|c|}
\hline $\begin{array}{l}\text { Sample } \\
\text { no }\end{array}$ & $\begin{array}{l}\text { Sample } \\
\text { content }\end{array}$ & $\begin{array}{c}\text { Temperature } \\
\text { at release } \\
\left({ }^{\circ} \mathrm{C}\right)\end{array}$ & $\begin{array}{l}\text { Peppas } \\
\text { equation }\end{array}$ & $\begin{array}{l}\text { Zero-order } \\
\text { model }\end{array}$ & $\begin{array}{l}\text { First-order } \\
\text { model }\end{array}$ & $\begin{array}{l}\text { Higuchi } \\
\text { model }\end{array}$ & $\begin{array}{l}\text { The } \\
\text { modified } \\
\text { Hixson- } \\
\text { Crowell } \\
\text { model }\end{array}$ \\
\hline \multirow[t]{3}{*}{1} & \multirow[t]{3}{*}{$\mathrm{PVA}+\mathrm{LM}$} & $5.5 \pm 1.5$ & $\begin{array}{c}\mathrm{k}=41.2 \times 10^{-3} \\
\mathrm{n}=0.24 \\
\mathrm{R}^{2}=0.95\end{array}$ & $\begin{array}{c}\mathrm{k}=7 \times 10^{-5} \\
\mathrm{R}^{2}=0.42\end{array}$ & $\begin{array}{c}-\mathrm{k}=8 \times 10^{-5} \\
\mathrm{R}^{2}=0.66\end{array}$ & $\begin{array}{c}\mathrm{k}=4.7 \times 10^{-3} \\
\mathrm{R}^{2}=0.78\end{array}$ & $\begin{array}{c}\mathrm{k}=1.06 \\
-\mathrm{n}=0.02 \\
\mathrm{R}^{2}=0.84\end{array}$ \\
\hline & & $20 \pm 1.0$ & $\begin{array}{c}\mathrm{k}=23.4 \times 10^{-3} \\
\mathrm{n}=0.37 \\
\mathrm{R}^{2}=0.97\end{array}$ & $\begin{array}{c}\mathrm{k}=9 \times 10^{-5} \\
\mathrm{R}^{2}=0.88\end{array}$ & $\begin{array}{c}-\mathrm{k}=20 \times 10^{-5} \\
\mathrm{R}^{2}=0.97\end{array}$ & $\begin{array}{c}\mathrm{k}=7.5 \times 10^{-3} \\
\mathrm{R}^{2}=0.96\end{array}$ & $\begin{aligned} \mathrm{k} & =1.35 \\
-\mathrm{n} & =0.07 \\
\mathrm{R}^{2} & =0.69\end{aligned}$ \\
\hline & & $38.5 \pm 1.5$ & $\begin{array}{c}\mathrm{k}=35 \times 10^{-3} \\
\mathrm{n}=0.24 \\
\mathrm{R}^{2}=0.95\end{array}$ & $\begin{array}{c}\mathrm{k}=6 \times 10^{-5} \\
\mathrm{R}^{2}=0.43\end{array}$ & $\begin{array}{c}-\mathrm{k}=7 \times 10^{-5} \\
\mathrm{R}^{2}=0.63\end{array}$ & $\begin{array}{c}\mathrm{k}=4 \times 10^{-3} \\
\mathrm{R}^{2}=0.78\end{array}$ & $\begin{aligned} \mathrm{k} & =1.05 \\
-\mathrm{n} & =0.02 \\
\mathrm{R}^{2} & =0.84\end{aligned}$ \\
\hline \multirow[t]{3}{*}{2} & \multirow[t]{3}{*}{$\begin{array}{l}\mathrm{PVA}+\mathrm{ALG} \\
+\mathrm{LM}\end{array}$} & $5.5 \pm 1.5$ & $\begin{array}{c}\mathrm{k}=20 \times 10^{-3} \\
\mathrm{n}=0.24 \\
\mathrm{R}^{2}=0.97\end{array}$ & $\begin{array}{c}\mathrm{k}=3 \times 10^{-5} \\
\mathrm{R}^{2}=0.30\end{array}$ & $\begin{array}{c}-\mathrm{k}=3 \times 10^{-5} \\
\mathrm{R}^{2}=0.43\end{array}$ & $\begin{array}{c}\mathrm{k}=2.2 \times 10^{-3} \\
\mathrm{R}^{2}=0.76\end{array}$ & $\begin{aligned} \mathrm{k} & =1.02 \\
-\mathrm{n} & =0.01 \\
\mathrm{R}^{2} & =0.90\end{aligned}$ \\
\hline & & $20 \pm 1.0$ & $\begin{array}{c}\mathrm{k}=22.9 \times 10^{-3} \\
\mathrm{n}=0.32 \\
\mathrm{R}^{2}=0.94\end{array}$ & $\begin{array}{c}\mathrm{k}=6 \times 10^{-5} \\
\mathrm{R}^{2}=0.86\end{array}$ & $\begin{aligned}-\mathrm{k} & =8 \times 10^{-5} \\
\mathrm{R}^{2} & =0.95\end{aligned}$ & $\begin{array}{c}\mathrm{k}=5.2 \times 10^{-3} \\
\mathrm{R}^{2}=0.93\end{array}$ & $\begin{aligned} \mathrm{k} & =1.15 \\
-\mathrm{n} & =0.04 \\
\mathrm{R}^{2} & =0.71\end{aligned}$ \\
\hline & & $38.5 \pm 1.5$ & $\begin{array}{c}\mathrm{k}=26.5 \times 10^{-3} \\
\mathrm{n}=0.24 \\
\mathrm{R}^{2}=0.95\end{array}$ & $\begin{array}{c}\mathrm{k}=4 \times 10^{-5} \\
\mathrm{R}^{2}=0.43\end{array}$ & $\begin{array}{c}-\mathrm{k}=5 \times 10^{-5} \\
\mathrm{R}^{2}=0.58\end{array}$ & $\begin{array}{c}\mathrm{k}=3.1 \times 10^{-3} \\
\mathrm{R}^{2}=0.78\end{array}$ & $\begin{aligned} \mathrm{k} & =1.03 \\
-\mathrm{n} & =0.01 \\
\mathrm{R}^{2} & =0.85\end{aligned}$ \\
\hline
\end{tabular}




\begin{tabular}{|c|c|c|c|c|c|c|c|}
\hline $\begin{array}{l}\text { Sample } \\
\text { no }\end{array}$ & $\begin{array}{l}\text { Sample } \\
\text { content }\end{array}$ & $\begin{array}{c}\text { Temperature } \\
\text { at release } \\
\left({ }^{\circ} \mathrm{C}\right)\end{array}$ & $\begin{array}{l}\text { Peppas } \\
\text { equation }\end{array}$ & $\begin{array}{l}\text { Zero-order } \\
\text { model }\end{array}$ & $\begin{array}{c}\text { First-order } \\
\text { model }\end{array}$ & $\begin{array}{l}\text { Higuchi } \\
\text { model }\end{array}$ & $\begin{array}{c}\text { The } \\
\text { modified } \\
\text { Hixson- } \\
\text { Crowell } \\
\text { model }\end{array}$ \\
\hline \multirow[t]{3}{*}{3} & \multirow[t]{3}{*}{$\mathrm{GL}+\mathrm{LM}$} & $5.5 \pm 1.5$ & $\begin{array}{c}\mathrm{k}=22.6 \times 10^{-3} \\
\mathrm{n}=0.25 \\
\mathrm{R}^{2}=0.95\end{array}$ & $\begin{array}{c}\mathrm{k}=4 \times 10^{-5} \\
\mathrm{R}^{2}=0.50\end{array}$ & $\begin{array}{c}-\mathrm{k}=4 \times 10^{-5} \\
\mathrm{R}^{2}=0.63\end{array}$ & $\begin{array}{c}\mathrm{k}=2.8 \times 10^{-3} \\
\mathrm{R}^{2}=0.81\end{array}$ & $\begin{array}{c}\mathrm{k}=1.03 \\
-\mathrm{n}=0.01 \\
\mathrm{R}^{2}=0.84\end{array}$ \\
\hline & & $20 \pm 1.0$ & $\begin{array}{c}\mathrm{k}=30.6 \times 10^{-3} \\
\mathrm{n}=0.30 \\
\mathrm{R}^{2}=0.93\end{array}$ & $\begin{array}{c}\mathrm{k}=7 \times 10^{-5} \\
\mathrm{R}^{2}=0.82\end{array}$ & $\begin{array}{c}-\mathrm{k}=10 \times 10^{-5} \\
\mathrm{R}^{2}=0.94\end{array}$ & $\begin{array}{c}\mathrm{k}=5.8 \times 10^{-3} \\
\mathrm{R}^{2}=0.92\end{array}$ & $\begin{array}{c}\mathrm{k}=1.10 \\
-\mathrm{n}=0.04 \\
\mathrm{R}^{2}=0.70\end{array}$ \\
\hline & & $38.5 \pm 1.5$ & $\begin{array}{c}\mathrm{k}=28.8 \times 10^{-3} \\
\mathrm{n}=0.25 \\
\mathrm{R}^{2}=0.95\end{array}$ & $\begin{array}{c}\mathrm{k}=5 \times 10^{-5} \\
\mathrm{R}^{2}=0.51\end{array}$ & $\begin{array}{c}-\mathrm{k}=6 \times 10^{-5} \\
\mathrm{R}^{2}=0.66\end{array}$ & $\begin{array}{c}\mathrm{k}=3.6 \times 10^{-3} \\
\mathrm{R}^{2}=0.81\end{array}$ & $\begin{array}{c}\mathrm{k}=1.04 \\
-\mathrm{n}=0.02 \\
\mathrm{R}^{2}=0.84\end{array}$ \\
\hline \multirow[t]{3}{*}{4} & \multirow[t]{3}{*}{$\begin{array}{l}\text { GL+ALG } \\
+\mathrm{LM}\end{array}$} & $5.5 \pm 1.5$ & $\begin{array}{c}\mathrm{k}=18.5 \times 10^{-3} \\
\mathrm{n}=0.26 \\
\mathrm{R}^{2}=0.96\end{array}$ & $\begin{array}{c}\mathrm{k}=4 \times 10^{-5} \\
\mathrm{R}^{2}=0.55\end{array}$ & $\begin{array}{c}-\mathrm{k}=4 \times 10^{-5} \\
\mathrm{R}^{2}=0.65\end{array}$ & $\begin{array}{c}\mathrm{k}=2.5 \times 10^{-3} \\
\mathrm{R}^{2}=0.84\end{array}$ & $\begin{array}{c}\mathrm{k}=1.03 \\
-\mathrm{n}=0.01 \\
\mathrm{R}^{2}=0.86\end{array}$ \\
\hline & & $20 \pm 1.0$ & $\begin{array}{c}\mathrm{k}=14.6 \times 10^{-3} \\
\mathrm{n}=0.28 \\
\mathrm{R}^{2}=0.93\end{array}$ & $\begin{array}{c}\mathrm{k}=3 \times 10^{-5} \\
\mathrm{R}^{2}=0.74\end{array}$ & $\begin{array}{c}-\mathrm{k}=3 \times 10^{-5} \\
\mathrm{R}^{2}=0.81\end{array}$ & $\begin{array}{c}\mathrm{k}=2.2 \times 10^{-3} \\
\mathrm{R}^{2}=0.91\end{array}$ & $\begin{array}{c}\mathrm{k}=1.04 \\
-\mathrm{n}=0.01 \\
\mathrm{R}^{2}=0.77\end{array}$ \\
\hline & & $38.5 \pm 1.5$ & $\begin{array}{c}\mathrm{k}=18.7 \times 10^{-3} \\
\mathrm{n}=0.27 \\
\mathrm{R}^{2}=0.95\end{array}$ & $\begin{array}{c}\mathrm{k}=4 \times 10^{-5} \\
\mathrm{R}^{2}=0.62\end{array}$ & $\begin{array}{c}-\mathrm{k}=4 \times 10^{-5} \\
\mathrm{R}^{2}=0.14\end{array}$ & $\begin{array}{c}\mathrm{k}=2.7 \times 10^{-3} \\
\mathrm{R}^{2}=0.86\end{array}$ & $\begin{array}{c}\mathrm{k}=1.03 \\
-\mathrm{n}=0.01 \\
\mathrm{R}^{2}=0.85\end{array}$ \\
\hline \multirow[t]{3}{*}{5} & \multirow[t]{3}{*}{$\begin{array}{l}\text { GL+LA } \\
+\mathrm{LM}\end{array}$} & $5.5 \pm 1.5$ & $\begin{array}{c}\mathrm{k}=26.1 \times 10^{-3} \\
\mathrm{n}=0.24 \\
\mathrm{R}^{2}=0.95\end{array}$ & $\begin{array}{c}\mathrm{k}=4 \times 10^{-5} \\
\mathrm{R}^{2}=0.45\end{array}$ & $\begin{array}{c}-\mathrm{k}=5 \times 10^{-5} \\
\mathrm{R}^{2}=0.60\end{array}$ & $\begin{array}{c}\mathrm{k}=3.1 \times 10^{-3} \\
\mathrm{R}^{2}=0.79\end{array}$ & $\begin{array}{c}\mathrm{k}=1.03 \\
-\mathrm{n}=0.01 \\
\mathrm{R}^{2}=0.85\end{array}$ \\
\hline & & $20 \pm 1.0$ & $\begin{array}{c}\mathrm{k}=18.3 \times 10^{-3} \\
\mathrm{n}=0.31 \\
\mathrm{R}^{2}=0.93\end{array}$ & $\begin{array}{c}\mathrm{k}=5 \times 10^{-5} \\
\mathrm{R}^{2}=0.84\end{array}$ & $\begin{array}{c}-\mathrm{k}=6 \times 10^{-5} \\
\mathrm{R}^{2}=0.92\end{array}$ & $\begin{array}{c}\mathrm{k}=3.8 \times 10^{-3} \\
\mathrm{R}^{2}=0.93\end{array}$ & $\begin{array}{c}\mathrm{k}=1.09 \\
-\mathrm{n}=0.02 \\
\mathrm{R}^{2}=0.73\end{array}$ \\
\hline & & $38.5 \pm 1.5$ & $\begin{array}{c}\mathrm{k}=40.9 \times 10^{-3} \\
\mathrm{n}=0.24 \\
\mathrm{R}^{2}=0.95\end{array}$ & $\begin{array}{c}\mathrm{k}=7 \times 10^{-5} \\
\mathrm{R}^{2}=0.43\end{array}$ & $\begin{array}{c}-\mathrm{k}=8 \times 10^{-5} \\
\mathrm{R}^{2}=0.66\end{array}$ & $\begin{array}{c}\mathrm{k}=4.7 \times 10^{-3} \\
\mathrm{R}^{2}=0.78\end{array}$ & $\begin{array}{c}\mathrm{k}=1.0600 \\
-\mathrm{n}=0.02 \\
\mathrm{R}^{2}=0.84\end{array}$ \\
\hline
\end{tabular}

PVA: polyvinyl alcohol; LM: limonene; ALG: alginate; LA: lactalbumin

The Higuchi model exhibited good correlation for all polymers at only $20^{\circ} \mathrm{C}$, indicating the release rate of LM decreased proportionally to the square root of time at $20^{\circ} \mathrm{C}$. The firstorder model had the same results at $20^{\circ} \mathrm{C}$, except for sample 4 . The first-order model indicates that the transport might be rate-limiting step (WANG et al., 2017). The modified HixsonCrowell model showed good fit for only sample 2 at $5.5^{\circ} \mathrm{C}$, whereas the zero-order model did not show any good correlation compared to the other models.

The values of $\mathrm{R}^{2}$ for the Peppas equation decreased as the temperature increased from $5.5^{\circ} \mathrm{C}$ to $20^{\circ} \mathrm{C}$ and then increased with further increases in temperature, except for sample 1 . The Higuchi model, which suggests the release mechanism might be different from quasiFickian at $20^{\circ} \mathrm{C}$, fitted well only at $20^{\circ} \mathrm{C}$. However, since the values of $\mathrm{R}^{2}$ for the Peppas 
equation were higher than the values of $\mathrm{R}^{2}$ for the Higuchi model at $20^{\circ} \mathrm{C}$, the release mechanism was Fickian (MeнTA et al., 2017). Probably, more than one mechanism was involved in the release. The different release kinetics can be explained by various factors including interactions between wall and core materials, the encapsulation methods, behaviour of wall polymers in release media, and different size of fibres (Ko \& GUNASEKARAN, 2014).

Interestingly, higher release amounts were determined at $20^{\circ} \mathrm{C}$ compared to the amounts released at $38.5^{\circ} \mathrm{C}$ (Supplementary data). It may be attributed to the nature of the structure of the protein-made wall polymers at high temperatures (except for samples 1 and 2). The temperature dependency of LM release was modelled by the Arrhenius equation. Only sample 2 (without protein wall polymer) obeyed the Arrhenius kinetic, which may indicate that for the other samples with protein the mechanisms were different as temperature increased. The Arrhenius constant and the activation energy for LM from the PVA+ALG encapsulation system were found as 0.28 and $6.2 \mathrm{~kJ} \mathrm{~mol}^{-1}$, respectively.

The release rate of antimicrobial compound plays an important role in maintaining food quality and safety. When the release rate of the antimicrobial agent is very slow, microbial growth might occur before the agent could inhibit it. When the release rate is too fast, the agent may diffuse into food and may not be available at the food surface to inhibit microbial growth (Uz \& Altinkaya, 2011). Delivery systems working with quasi-Fickian diffusion may provide solution for hydrophilic and volatile core materials (BASAK et al., 2008) like LM.

Active food packaging provides inert barrier including antimicrobial bioactive compounds such as LM. Using electrospun fibres as active packaging material is preferred due to its submicron diameters, high sensitivity to changes, and suitability for encapsulation of heat-sensitive compunds (Vega-Lugo \& Lim, 2009; Anu Bhushani \& ANANDHARAMAKRISHNAN, 2014). LM, as a natural and non-toxic product with good flavour (LI \& ChiAng, 2012), is acceptable to be a food contact packaging material (NeO et al., 2013). The parameters of electrospinning for encapsulation of active compounds have been studied by VeGA-Lugo \& Lim (2009).

The gradual release of electrospun encapsulated LM by various polymers appears to be applicable to active food packaging, however, more studies, especially application for food products is needed.

\section{Conclusions}

In conclusion, the encapsulation of LM was succesfully achieved by uniaxial electrospinning using PVA or GL, which presented the two highest EE, as wall materials. Release kinetics of uniaxial electrospun encapsulated LM was fitted by the Peppas equation at all temperatures, indicating quasi-Fickian diffusion. Especially the gradual release of LM would be beneficial in active food packaging for its antibacterial properties. The outcomes of this work would be beneficial for future studies on release kinetics of bioactive materials from electrospun systems used in active food packaging.

Dr. Filiz Altay acknowledges the financial support from TUBITAK for the project no:113O491. Mr. Dede thanks Nagihan Okutan and Büşra Bakır for their help on electrospinning, dls and contact angle measurements. Mr. Dede also thanks Prof. Dr. Yahya Kemal Avsar for chromatographical analyses. 


\section{References}

Altay, F. \& Okutan, N. (2015): Nanofiber encapsulation of active ingredients and their controlled release. -in: Ravishankar R.V. (Ed.) Advances in food biotechnology, Wiley-Blackwell, West Sussex, UK. Chapter 37, pp. $607-616$.

Anu Bhushani, J. \& Anandharamakrishnan, C. (2014): Electrospinning and electrospraying techniques: Potential food-based applications. Trends Food Sci. Tech., 38, 21-33.

Baner, A., Bieber, W., Figge, K., Franz, R. \& Piringer, O. (1992): Alternative fatty food simulants for migration testing of polymeric food contact materials. Food Addit. Contam., 9(2), 137-148.

Basak, S.C., Kumar, K.S., Ramalingam, M. (2008): Design and release characteristics of sustained release tablet containing metformin HCl. Braz. J. Pharm. Sci., 44(3), 476-483.

Bhattarai, N., Li, Z., Edmondson, D. \& Zhang, M. (2006): Alginate-based nanofibrous scaffolds: Structural, mechanical and biological properties. Adv. Mater., 18, 1463-1467.

Bueno, V.B., Bentini, R., Catalani, L.H. \& Petri, D.F.S. (2012): Synthesis and swelling behavior of xanthan-based hydrogels. Carbohyd. Polym., 92(2), 1091-1099.

Camerlo, A., Buhlmann-Popa, A., Vebert-Nardin, C., Rossi, R.M. \& Fortunato, G. (2014): Environmetally controlled emulsion electrospinning for the encapsulation of temperature-sensitive compounds. J. Mater. Sci., 49, 8154-8162.

Dong, J., Ghiladi, R.A., Wang, Q., Cai, Y. \& WeI, Q. (2018): Protoporphyrin-IX conjugated cellulose nanofibers that exhibit high antibacterial photodynamic inactivation efficacy. Nanotechnology, 29(26), 265601.

El-Leithy, E., Shaker, D.S. Ghorab, M.K. \& Abdel-Rashid, R.S. (2010): Optimization and characterization of diclofenac sodium microspheres prepared by a modified coacervation method. Drug Discov. Ther., 4(3), 208216.

Flores, F.P., Singh, R.K., Kerr, W.L., Pegg, R.B. \& Kong, F. (2014): Total phenolics content and antioxidant capacities of microencapsulated blueberry anthocyanins during in vitro digestion. Food Chem., 153, 272-278.

Gourdel, Y. \& Tronel, J. (2001): Flavoured gelatin capsules capable of containing various substances used in the food, animal feed, dietetic and pharmaceutical sectors. French Patent Application FR 2, 807677 A1.

Ko, S. \& Gunasekaran, S. (2014): Controlled release of food ingredients. -in: Kwak, H.S. (Ed.) Nano and microencapsulation for foods. John Wiley and Sons Ltd, $1^{\text {st }}$ ed. pp. 327-344.

Levi, S., Rac, V., Manojlovi, V., Raki, V., Bugarski, B., Flock, T., Krzyczmonik, K.E. \& Nedovi, V. (2011): Limonene encapsulation in alginate/poly (vinyl alcohol). Proc. Food Sci., 1, 1816-1820.

Li, P. \& Chiang, B. (2012): Process optimization and stability of D-limonene-in-water nanoemulsions prepared by ultrasonic emulsification using response surface methodology. Ultrason. Sonochem., 19, 192-197.

Mehta, P., Al-Kinani, A.A., Arshad, M.S., Chang, M., Alany, R.G. \& Ahmad, Z. (2017): Development and characterization of electrospun timolol maleate-loaded polymeric contact lens coatings containing various permeation enhancers. Int. J. Pharm., 532, 408-420.

Neo, Y.P., Swift, S., Ray, S., Gizdavic-Nikolaidis, M., Jin, J. \& Perera, C.O. (2013): Evaluation of gallic acid loaded zein-sub-micron electrospun fibre mats as novel active packaging materials. Food Chem., 141(3), 3192-3200.

Okutan, N., Terzi, P. \& Altay, F. (2014): Affecting parameters on electrospinning process and characterization of electrospun gelatin nanofibers. Food Hydrocolloid., 39, 19-26.

Ritger, P.L. \& Peppas, N.A. (1987): A simple equation for description of solute release I. Fickian and non-Fickian release from non-swellable devices in the form of slabs, cylinders or discs. J. Control. Release, 5(1), 23-36.

Rutz, J.K., Zambiazi, R.C., Borges, C.D., Krumreich, F.D., Da Luz, S.R., Hartwig, N. \& Da Rosa, C.G. (2013): Microencapsulation of purple Brazilian cherry juice in xanthan, tara gums and xanthan-tara hydrogel matrixes. Carbohyd. Polym., 98(2), 1256-1265.

Uz, M. \& Altinkaya, S.A. (2011): Development of mono and multilayer antimicrobial food packaging materials for controlled release of potassium sorbate. LWT-Food Sci Technol., 44, 2302-2309.

Vega-Lugo, A.C. \& Lim, L.T. (2009): Controlled release of allyl isothiocyanate using soy protein and poly (lactic acid) electrospun fibers. Food Res. Int., 42(8), 933-940.

Venturini, C.G., Jäger, E., Oliveira, C.P., Bernardi, A., Battastini, A.M.O., Guterres, S.S. \& Pohlmann, A.R. (2011): Formulation of lipid core nanocapsules. Colloid Surface A, 375(1-3), 200-208.

Vijayaragavan, S., Vino, S., Kalyani Rath, S., Mishra, B., Ghosh, A. \& Jayaraman, G. (2014): Controlled release of a water soluble drug, metoprolol succinate, by $\alpha$-lactalbumin microparticles. Int. J. Pharm. Pharm. Sci., 6, $762-767$.

WANG, H., HAO, L., WANG, P., Chen, M., JiAng, S. \& JIANG, S. (2017): Release kinetics and antibacterial activity of curcumin loaded zein fibers. Food Hydrocolloid., 63, 437-446. 